\title{
Low-Strength Substrates and Anthropogenic Soils in Transportation Engineering
}

https://doi.org/10.2478/sgem-2018-0029

received October 29, 2018; accepted November 7, 2018.

Abstract: Road embankments, especially their slopes' surfaces, must fulfil all the requirements concerning the exploitation criteria after the completion of construction works. This is very important while constructing or modernizing the embankments, based on the substrate including low-strength soils as well as in simple ground conditions (most convenient). The last dozen or so years of intensive construction of transport infrastructure have shown how big is the problem of ensuring the required volumes of qualified soil material for the construction of road embankments or the modernization of railway embankments. The depleting deposits of natural and easily accessible soils for the construction of embankments result in the need to use anthropogenic soils, for example, in the form of aggregates from the recycling of construction waste and other locally available waste materials, usually in the form of slag and ashes from the combined heat and power plants. In such cases, there's a need to treat transportation earth structures individually in the scope of designing and quality control, because there are no applicable standard provisions in this scope.

This work indicates some of these important contemporary problems of transport engineering, occurring in newly built and modernized road objects, such as the stability of road embankments based on a low-strength substrate, use of anthropogenic soils and materials originating from the recycling of concrete surfaces for the construction of road embankments.

Keywords: Transport engineering; road embankments; soft soils; anthropogenic soils.

\footnotetext{
*Corresponding author: Andrzej Batog, Elżbieta Stilger-Szydło, Wroctaw University of Science and Technology, Faculty of Civil Engineering, Wroctaw, Poland, E-mails: Andrzej.Batog@pwr.edu.pl; Elzbieta.Stilger-Szydlo@pwr.edu.pl
}

\section{Introduction}

The need to conduct construction works (formation of embankments and cuttings) in the areas where substrates contain low-strength mineral soils and organic soils, occurs in transportation engineering much more often than in other sectors of construction. Road embankments (and mainly their surfaces) constructed or modernized in the conditions of retention of the low-strength soils in the substrate, fulfilall exploitation criteria after the completion of works; similarly, as the embankments are formed in simple (most convenient) soil conditions. Difficult and complex soil conditions that occur in the substrate, to a large extent, increase the possibility of failures of the road embankments, which result in the destruction of surface structure. This is affected by many factors additional to the above-mentioned complex and complicated geological-engineering conditions of the substrate. It may also include an inappropriate selection of the material of embankment body or its improper performance or poor anti-erosion protection of the slopes. The last dozen or so years of intensive construction of transport infrastructure have shown how big the problem is of ensuring the required volumes of qualified soil material for the construction of road embankments or modernization of railway embankments. Even the relatively short, up to a dozen or so kilometres long, sections of constructed expressways required the provisions of more than a million cubic metre of soil masses. The depleting deposits of natural and easily accessible soils for the construction of embankments result in the need to use anthropogenic soils, for example, in the form of aggregates from the recycling of construction waste and other locally available waste materials, usually in the form of slag and ashes from the combined heat and power plants. In such cases, there's a need to treat transportation earth structures individually in the scope of designing and quality control, because there are no applicable standard provisions in this scope.

This work indicates some of these important contemporary problems of transport engineering, occurring in newly built and modernized road objects. In 
their earlier works [3], [4] and [5], the authors discussed in detail the methods for assessing the stability of slopes of the road embankments and presented discussions concerning the interpretation of the obtained results, including the assessments of the required stability margins of slopes, which took into account various criteria regarding the required value of slope factor of safety, used in recent years (Polish Standards, regulations, Eurocode 7, etc.). This work uses results from a dozen or so analysed cross-sections and sections of embankments of newly built and modernized roads in Poland, characterized by high variability of foundation conditions or the use of anthropogenic soils for the construction of embankment body.

\section{Stability of Road Embankments Based on a Low-Strength Substrate}

The selection of the foundation method and the performance technology of road embankments based on weak subsoil is affected by:

- location of road gradeline in relation to the existing area, which determines the acceptance of the appropriate height of the embankment

- location of the ceiling of low-strength soils in relation to the land surface, as well as their type, thickness and arrangement of layers in the transverse and longitudinal profile of the embankment

- intended use of the embankment (road category, load class)

- availability of construction site for the use of construction equipment, time and costs of investment implementation

The above-mentioned factors determine the selection of appropriate (in the given case) technology of foundation and construction of embankments on low-strength soils. Figure 1 illustrates one of the examples of cracks in the surface resulting from uneven settlement of the road embankment. In the considered case, during modernization of the existing road, the embankments were widened and their height was increased. The embankment was widened on both sides, one slope/side by $3.0 \mathrm{~m}$ and the other by 1.0-1.5 $\mathrm{m}$. The embankment of existing road was stabilized, but suspended in the layer of peat that was left in the substrate. The remaining peats belonged to the compact peats ( $w_{n}<500 \%$ ). Groundwater was present in the embankment's base at a depth of $0.2 \div$

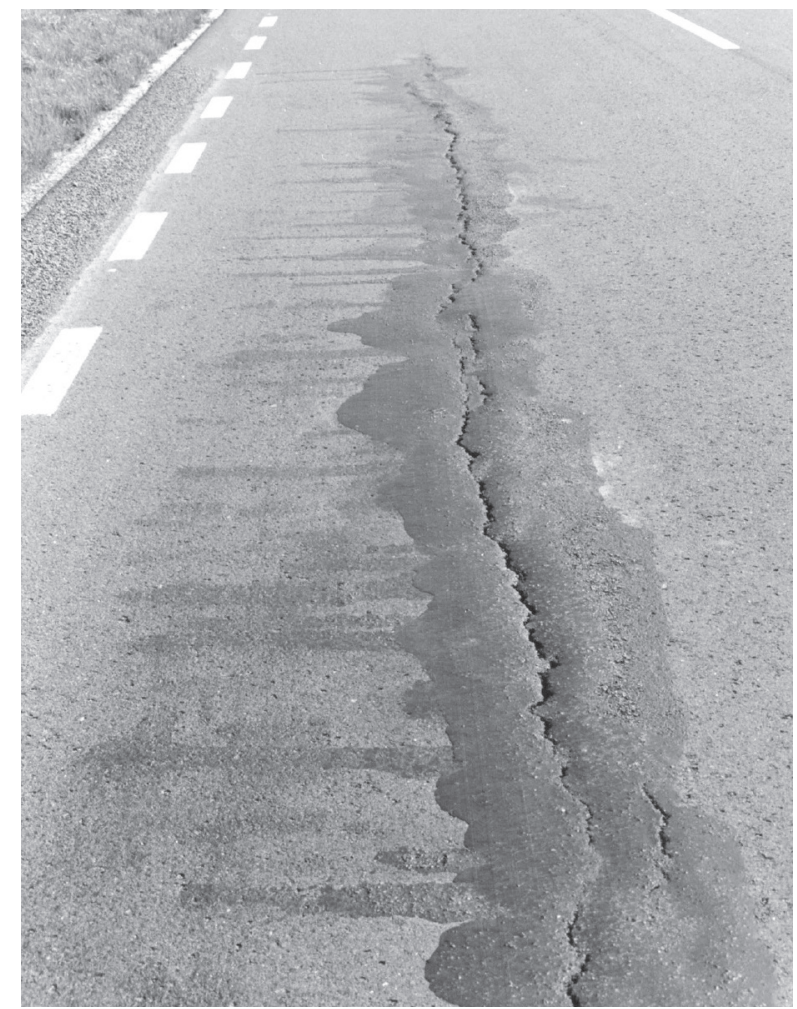

Figure 1: Longitudinal crack in the surface as a result of uneven settlement of the embankment.

1.3 below ground level, subject to fluctuations, on average amounting to $0.5 \mathrm{~m}$. Widening of the embankment was based on the old road embankment, while its crown in the extreme case reached approx. $0.5 \mathrm{~m}$ above the crown of the old embankment. Due to savings, the substrate under the embankment was not reinforced. The old embankment was connected with the new one via shelves and the system of geosynthetics.

Figure 2 shows the graph of the embankment's settlement after 43 months of road exploitation. The forecasted final settlement of the embankment amounted to $41 \mathrm{~cm}$, while the analysis of measurement results indicated the maximum settlement of the embankment, over a period of approximately 43 months, amounting to $25 \mathrm{~cm}$. The highest values of settlement were observed in the axis and on the left edge of the roadway, while much lower values were observed on the right edge. This means that there's a possibility of further settlement of the embankment in the period of approximately four years. After the period of stabilization of the embankment, the final renovation of the surface will be designed, while in the meantime, maintenance procedures will be carried out. 


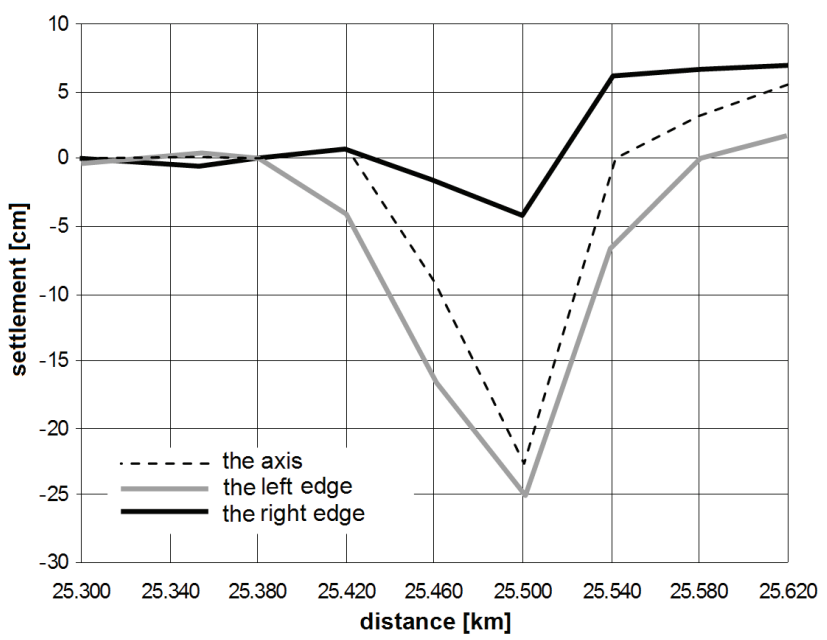

Figure 2: Measurement results of settlement of the embankment (in the axis, on the left and right edges of the roadway).

On one hand, the presented example shows the impact of effects of embankment settlement on the condition of road surface, and on the other hand - the Investor's strategy, which, due to significant costs, did not decide to strengthen the substrate. An additional factor that hindered the strengthening of the substrate was the impossibility of organizing bypass routes of the subject road. It's also apparent how important it is to consider the limit state of use in designing. With a well-compacted embankment and low load exerted on a supporting subsoil, deformations caused by own weight of the embankment or the load will not exceed the permissible values. It is also necessary to foresee the possibility of occurrence of deformations caused by a change in water conditions, including long-term settlements, caused by changes in moisture of the embankment and substrate.

Embankments constructed on low-strength soils are subject to significant deformations due to their compressibility and plastic deformation of the substrate. During their construction and exploitation, it is necessary to take into account the occurrence of loss of limit load carrying capacity of the organic substrate, sinking of the embankment and displacement of the weak substrate, as well as loss of stability of the embankment, and significant as well as long-term settlements of the organic substrate. Prevention of these unfavourable conditions consists of proper designing, selection of the appropriate method of foundation and embankment performance technology, as well as conducting the monitoring of these structures. Applied methods for assessing the limit state of exploitation of these road embankments should use the compressibility parameters of the organic substrate from appropriately carried out laboratory tests and from the developed correlation dependencies. ${ }^{[11]}$

The example illustrated above (figure 1) shows that only embankments of low height, which exert small loads, can be safely placed on low-strength soils without the need to reinforce the substrate. However, taking into account the high values of settlements, it is necessary in such cases to assume the appropriate method of embankment formation, for example, the staged construction, adapted to the forecasted size of final settlements, as well as the stabilization time of settlements of the substrate.

In the case of a need to place high embankments on low-strength organic substrate, even in the case of a relatively small thickness of such a layer, there will occur a great risk of the loss of stability of the embankment escarpment. Figure 3a presents another example of the stability assessment of embankment escarpment of the Expressway S-8 with the height of $7.0 \mathrm{~m}$, placed on a layer of plasticized clay silts with the thickness of $1.2 \mathrm{~m}$. Replacement of the low-strength layer for eligible soil material predicted for the formation of the embankment is the simplest and the most reliable manner of providing the required (in the period when the embankment was designed) value of factor of safety $\mathrm{F}_{\min }>1.5$ in the scope of issue of the escarpment's global stability. However, in the case of shallow slip surfaces, the stability margin required by the regulations ${ }^{[21]}$ is still not ensured (Figure $3 \mathrm{~b}$ ), $\mathrm{F}_{\min }=$ 1.3. Thus, it is necessary to form slopes in the technology of reinforced soil or to change the soil predicted as being built into the embankment to low plasticity soil - in this case, for clayey sand with a cohesion not lower than 12 $\mathrm{kPa}$, which will ensure the achievement the minimum value of factor of safety $\mathrm{F}_{\min }>1.5$.

\section{Use of Anthropogenic Soils for the Construction of Road Embankments}

An important problem, which has been intensifying in the recent years during the implementation of many road investments, is the shortage of eligible soil material. In urban areas, the deposits of good soil material are depleted. At the same time, there are locally available anthropogenic materials referred to as industrial waste. Materials such as slag, burnt and unburnt shale, or ashslag mixtures can be useful for the construction of road embankments without restrictions or with restrictions (according to PN-B-06050:1999 ${ }^{[15]}$ ), such as slag, burnt 

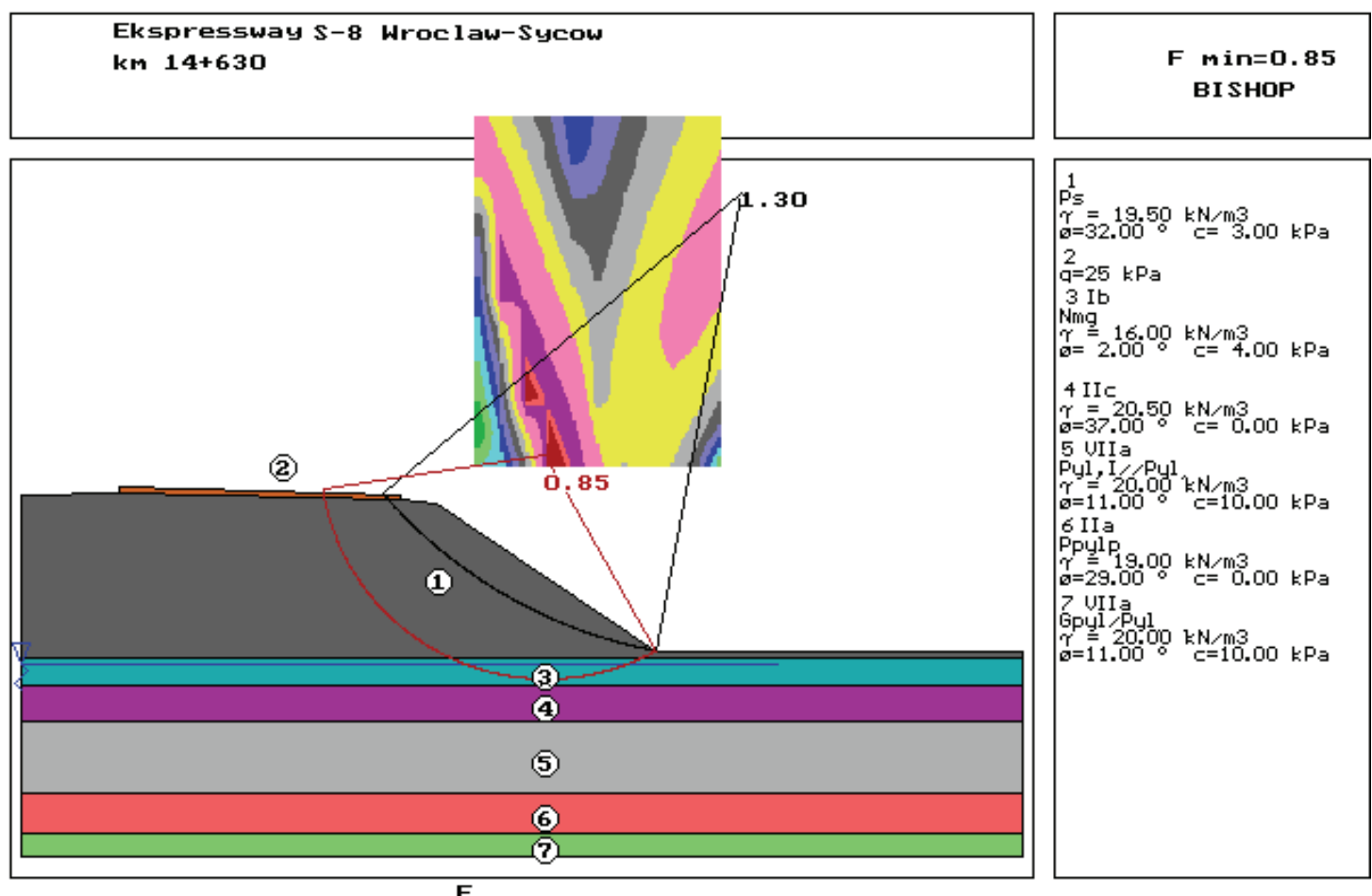

$\begin{array}{llllllllllllll}0.8 & 1.0 & 1.0 & 1.1 & 1.4 & 1.5 & 1.7 & 1.8 & 1.9 & 2.1 & 2.2 & 2.3 & 2.5\end{array}$

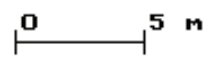

Figure 3a: Expressway S-8 Wroctaw-Syców, cross-section at km $14+630$ - embankment placed directly on the layer of silts (stability assessment performed according to [21]).
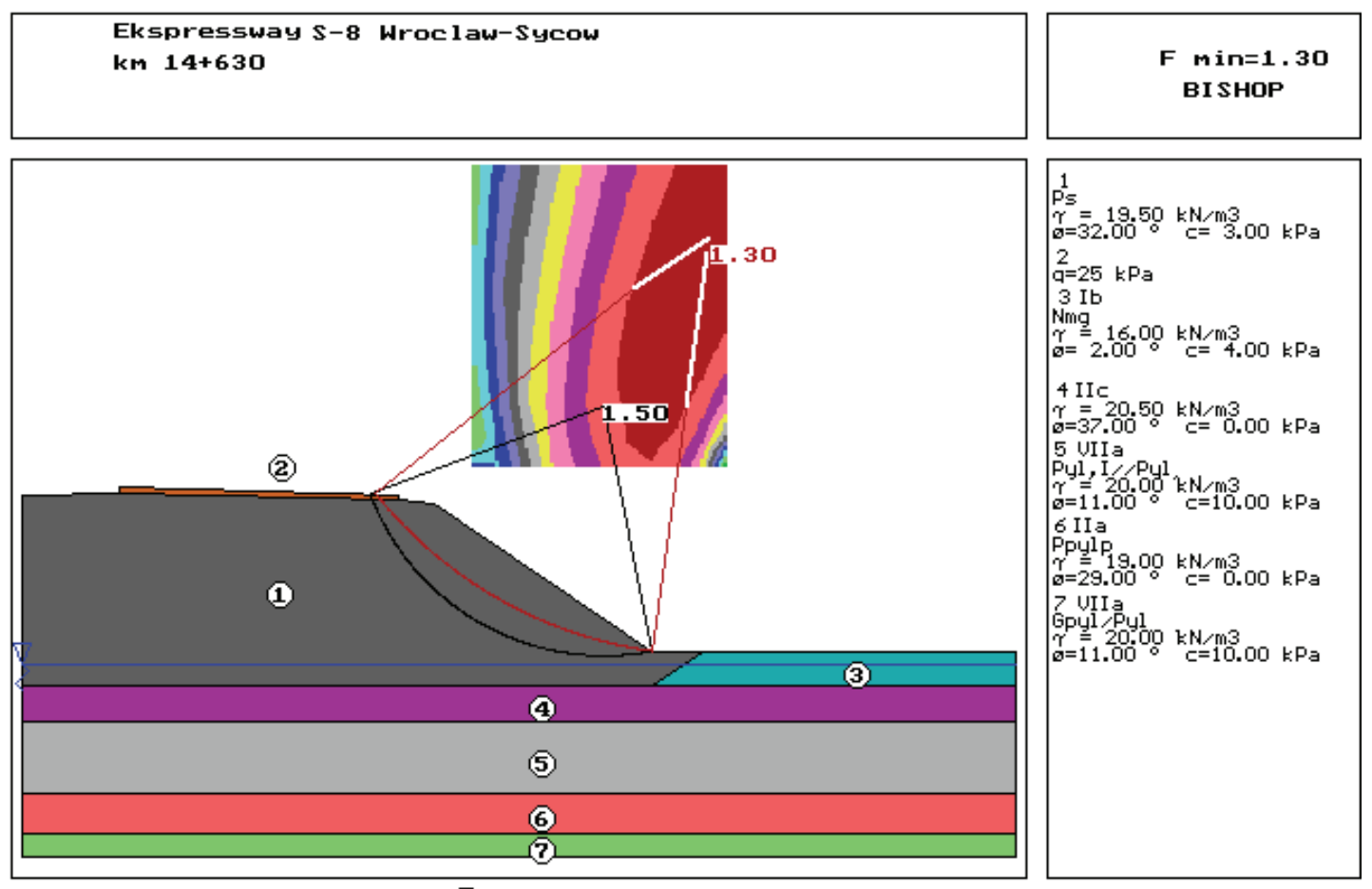

$\begin{array}{lllllllllllllll}1.3 & 1.5 & 1.6 & 1.8 & 1.9 & 2.1 & 2.2 & 2.3 & 2.5 & 2.6 & 2.8 & 2.9 & 3.1\end{array}$

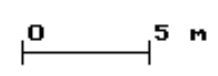

Figure 3b: Expressway S-8 Wroctaw-Syców, cross-section at km 14+630 -replacement of the layer of silts. 
and unburnt shale, or ash-slag mixtures. Relatively easily accessible materials are furnace or construction waste (after their proper processing ${ }^{[2]}$ ), which can be used as the components of mixtures with mineral soils for the forming of road embankments.

As an example, the application of anthropogenic material for the construction of road embankments in the Wroclaw region was presented, in the form of a mixture of natural sandy soil, originating from the local retention reservoir and furnace waste (ash-slag mixture) deposited in the landfill of local combined heat and power plant. ${ }^{[1]}$

In order to carry out a reliable stability analysis of embankment slopes formed from anthropogenic materials, it is very important to correctly determine the values of shear strength parameters, which may significantly differ from the typical ('standard') values given for the natural mineral soils ${ }^{[10]}$ and are strongly dependent on the type and proportion of mixed components. Figure 4 presents a graph demonstrating the range of variability of shear strength for several ash-sand mixtures, in reference to the height of the designed embankment.

Parametric analyses of the stability of embankment slopes formed from ash-sand mixtures were conducted. In the calculations of analysed types of mixtures and the height of embankment, the escarpment inclination size was sought, which ensures the achievement of factor of safety required by the Regulation, ${ }^{[21]}$ that is, $F_{\min }=1.50$. Example of the results of calculations carried out in the case of embankment with the height of $12 \mathrm{~m}$ and the escarpment inclination $1: 1$ is shown in Figure 5.

Stability calculations carried out in accordance with the Regulation of the Ministry of Transport and Water Management. ${ }^{[21]}$

The safe slope gradient of road embankment slopes made of ash-sand mixtures, which were determined in the calculations, are presented in Figure 6. The graph indicates that in the case of the lowest values of the strength parameters of the mixture, a constant safe slope gradient $1: 2.5$ was obtained, regardless of the embankment height. This results from the position of the most dangerous slip surface, which passes through the shallowest parts of the embankment, regardless of the embankment height.

Subsequently, the question was posed whether thesafe slope gradient of slopes determined this way, according to the criterion $F_{\text {min }}=1.50$ also meet the criteria included in the Eurocode 7 (with the use of design approach DA3). After carrying out the verifying calculations in all analysed schemes, it was found that the minimum value of factor of safety according to Eurocode 7 amounted to $F_{\min E C}>1.20$. In relation to the value required by Eurocode $7\left(F_{\text {req } E C}=1\right)$, the analysed slopes possibly could have greater gradient.

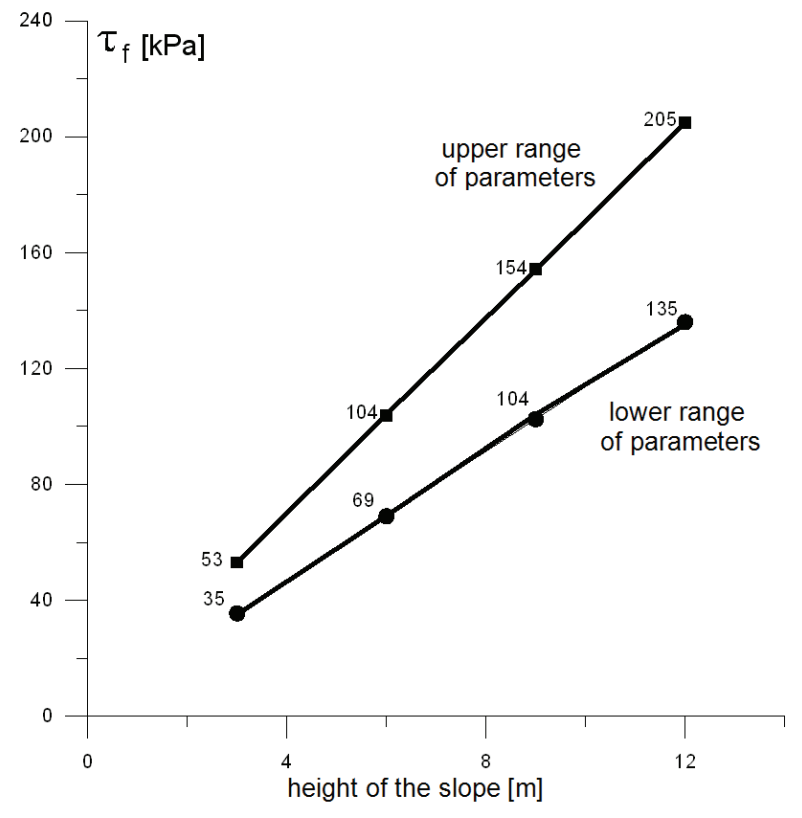

Figure 4: Dependence of limit resistance to shearing $\tau_{f}$ of the ashsand mixtures, depending on the embankment height ${ }^{[1]}$.

\section{Usefulness of Materials Originating from the Recycling of Concrete Surfaces in The Scope of Construction of Road Embankments}

The problem indicated above, which consists of high demand in road engineering for eligible soil material, is the reason for the increasing application of anthropogenic soil materials. From an economic and technical point of view, crushed concrete waste can constitute an alternative source of aggregate, replacing the natural/ broken aggregate. In the Research Laboratory of Transport Infrastructure Facilities (also accredited by PCA - no. AB 1211), a series of special geotechnical studies of anthropogenic soil material, originating from recycling of concrete surfaces in concrete crushers, were conducted. [9] Their results provide positive prognosis in regard to the possibility of its application in the scope of performance of filtration layers, strengthening of the substrate and construction, as well as strengthening of the slopes of road embankments.

Aggregate from recycling of concrete surfaces can be used in the top layers of the embankment, embankment slopes and in reinforced substrate of the embankment, in mixtures with natural aggregate, soil or independently, provided that the requirements of PN-S-02205:1998 ${ }^{[17]}$ are 


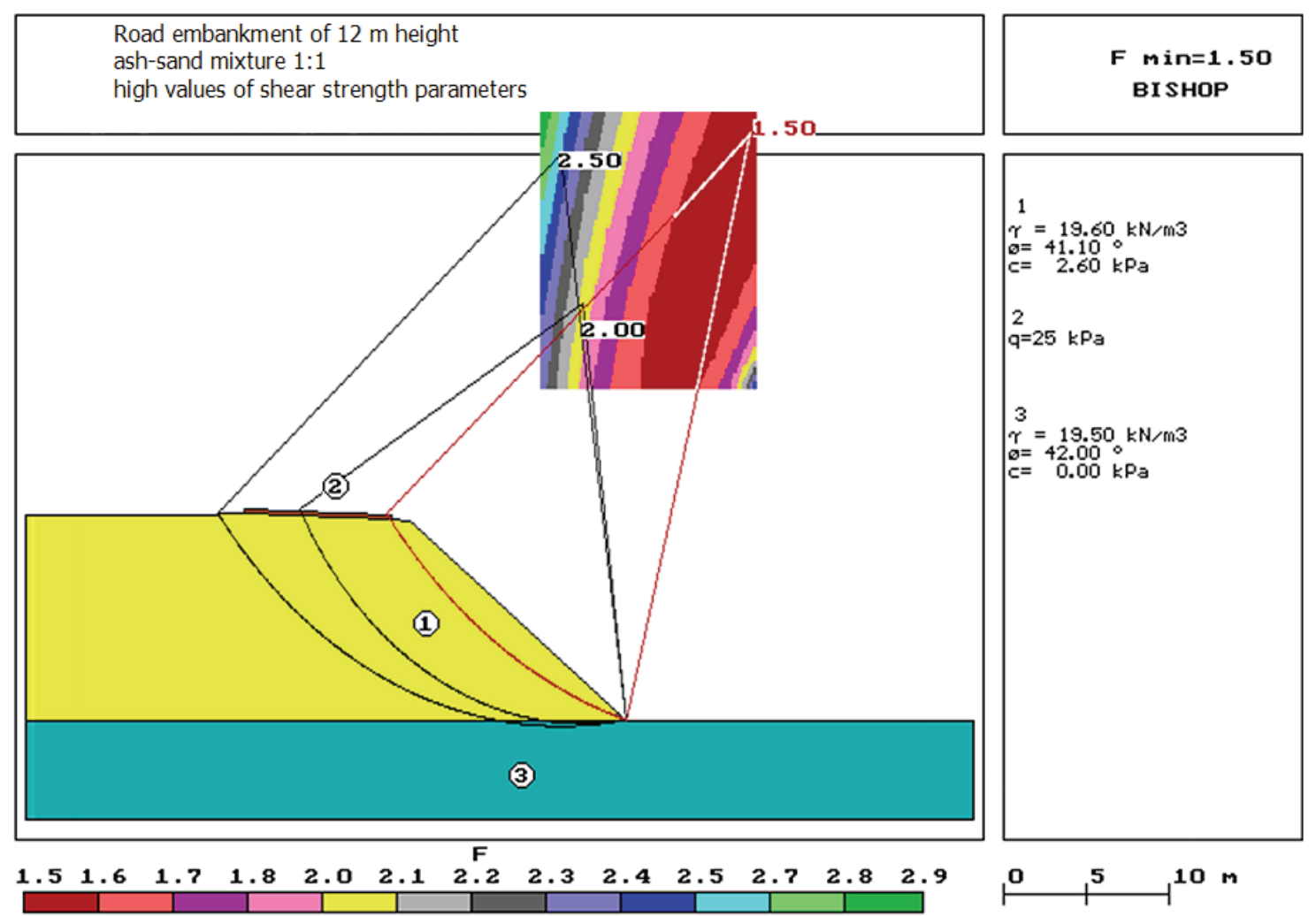

Figure 5: Embankment with the height of $12 \mathrm{~m}$, made of ash-sand mixture.

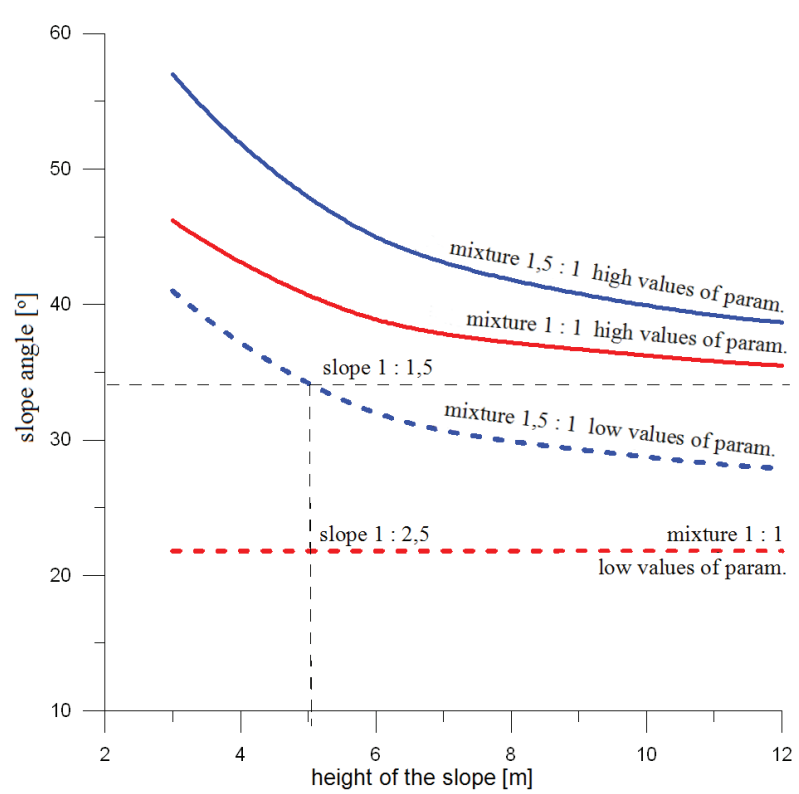

Figure 6: Safe slope gradient of the road embankment formed from ash-sand mixtures in the function of embankment height - results obtained for the factor of safety $F_{\min }=1.5$ [1].

met. The requirements imposed on aggregates for the top layers of the embankment are determined in Table 1.
Table 1: Requirements of aggregate for the top layers of the embankment.

\begin{tabular}{llll}
\hline Coefficients & Standards & Unit & Requirement \\
\hline Hydraulic & PKN-CEN ISO/TS & {$[\mathrm{m} / \mathrm{s}]$} & $>6 \times 10^{-5}$ \\
$\begin{array}{l}\text { Conductivity k } \\
\text { Coefficient of }\end{array}$ & PN-88/B-04481 & & \\
uniformity, $C_{u}$ & & - & $>5$ \\
\hline
\end{tabular}

Examinations of cohesion and the angle of internal friction ${ }^{[9]}$ indicate the possibility of using concrete aggregate for the construction and strengthening of embankment slopes. At the same time, it was found that there's a limited usability of concrete aggregate for the improvement of cohesive materials, unsuitable for the construction and strengthening of embankment slopes. The addition of economically justified quantities of concrete rubble (approx. 20\%) to the cohesive material in the on-site mixing technology, under construction conditions, results in an insignificant change in the cohesion parameters and the angle of internal friction. At the same time, the addition to the concrete rubble of even small amounts (approx. 20\%) of cohesive material results in a significant decrease in the angle of internal friction. Simultaneously, it should be noted that the mixture of 


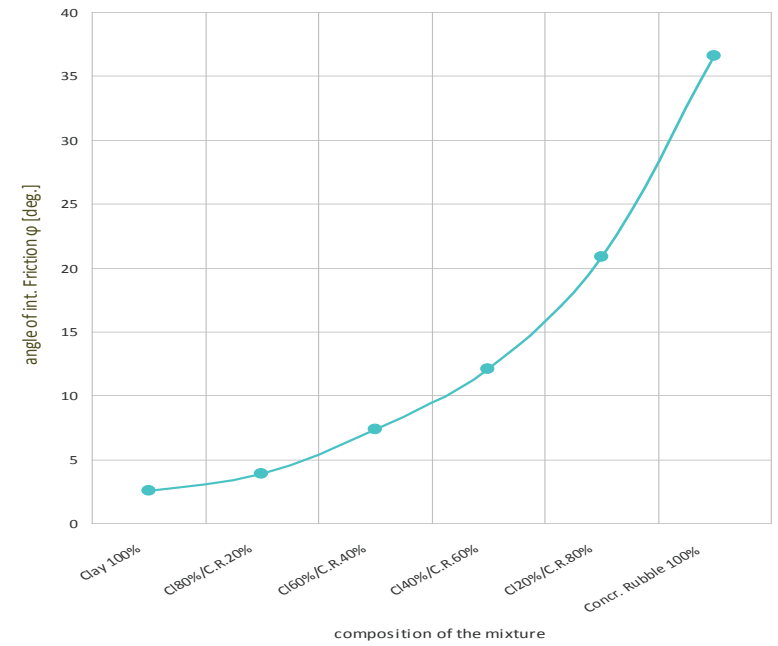

Figure 7: Change in the angle of internal friction $\phi$, depending on the composition of the mixture.

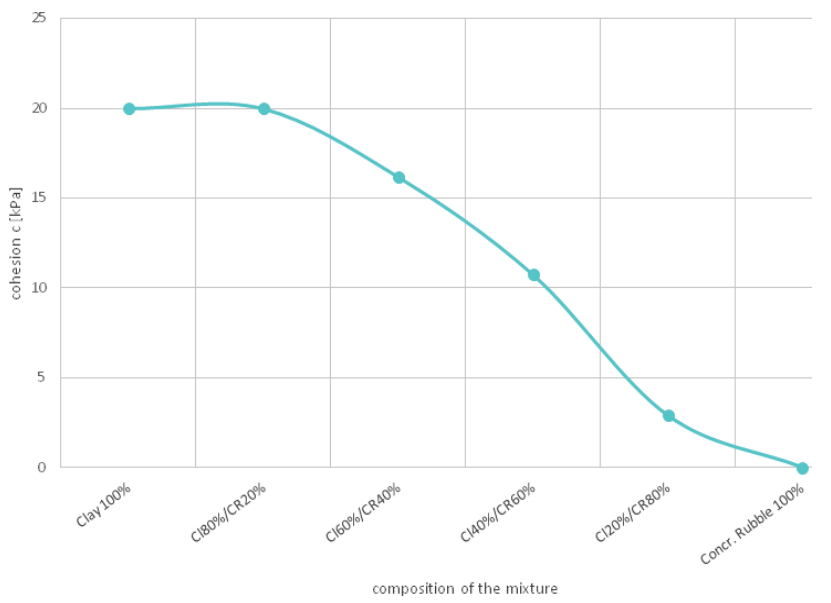

Figure 8: Change in the cohesion c, depending on the composition of the mixture.

cohesive material and concrete aggregate compacts in a better manner, than any of these materials separately.

Estimated values of the angle of internal friction, cohesion and bulk density of the skeleton of the concrete rubble and representative cohesive soil (clay) for the forming of slopes, are illustrated in figures 7, 8 and 9. ${ }^{[9]}$

Conducted laboratory tests of anthropogenic soil material, generated as a result of crushing and sieving processes of material originating from the recycling of concrete surfaces, as well as its mixing with clay, demonstrated that it has properties of coarse-grained non-cohesive soils or low plasticity soils. ${ }^{[9]}$ This depends on the percentage content of clay added to the concrete rubble (from 20 to $80 \%$ ).

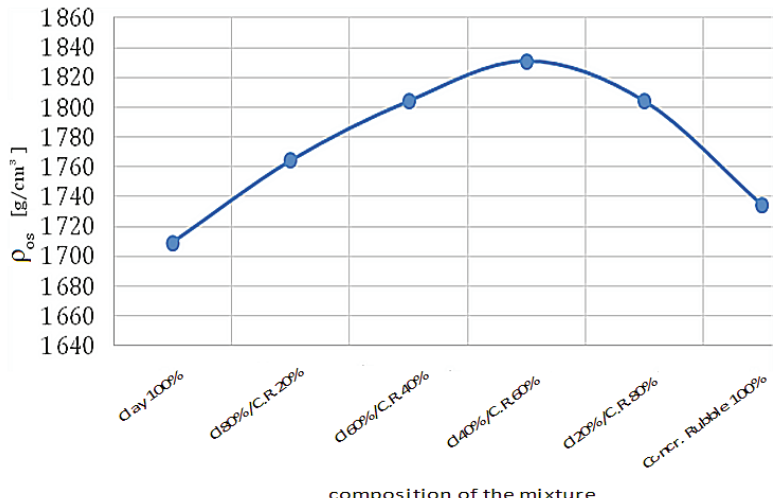

Figure 9: Change in the maximum bulk density of the skeleton, depending on the composition of the mixture.

Performed example stability analyses of slopes of the road embankment with the heights up to $10.0 \mathrm{~m}$, placed on supporting substrate (with the escarpment inclination 1:1.5) - demonstrated that they do not require reinforcement, provided the use of soils for the construction with the values of shear strength not smaller than: $\phi=15,17^{\circ}$ and $c=17,22 \mathrm{kPa}$.

This corresponds to the specified example estimated values of the angle of internal friction and cohesion of the mixture of concrete rubble and clay. However, the load carrying capacity of substrate has a big influence on the stability of embankment slopes. Thus, each case of road earthen structure requires individual analyses in terms of their stability and load carrying capacity of the substrate.

In the case of the occurrence of low-strength substrate (compressible soils) under the road embankment, whose load carrying capacity is lower than the embankment load, the substrate must be strengthened with the use of a stone mattress wrapped with a geogrid $\left(R_{r}=50 \mathrm{kN} / \mathrm{m}\right)$. The mattress should be placed at the base of the embankment, after removal of the humus. Mattress thickness $0.35 \mathrm{~m}$; aggregate with the grain size $0 / 63$ should have a degree of compaction greater than Dc $=0.98$; on the top mattress surface $E \geq 80 \mathrm{MPa}$; geogrid should be manufactured in accordance with the requirements of the quality standard ISO 9002 (EN 29002).

\section{Conclusions}

1. Stability assessment of road embankments is one of the main issues in the design process, ensuring safety of road exploitation. After introducing in 2016, the possibility of stability assessment of road escarpments with accordance to Eurocode 
7, the factor of safety $\mathrm{F}$, which is used as the basic parameter for assessing the stability margin, can assume various values, depending on the applied calculation method and adopted design approach. As indicated by the results specified in this work, the use of design approach DA 3, which is recommended by the Polish National Annex to the Eurocode 7, for stability calculations of road embankments can be beneficial in the case of occurrence of simple ground conditions in the substrate, as well as the use of good quality soil material or, for example, the material originating from the recycling of concrete surfaces. In less favourable cases, the stability margin ensured by the applied design approach DA 3 can be debatable.

2. In the case of formation of the road embankments from anthropogenic materials, the essential role in the scope of ensuring the safety of their exploitation is played by correct assessment of the values of parameters characterizing their shear strength. It is necessary to develop procedures enabling better and more effective control of the density of embankments formed from anthropogenic soils, which will take into account the specificity of these materials that in some cases are very much different than the native soils.

3. Undertaking works aimed at introducing detailed guidelines and algorithms for assessing the stability of slopes of embankments and cuttings, based on the recommendations of Eurocode 7, seems to be urgent, taking into account the specificity of transportation earth structures, including those formed from anthropogenic soils, which are placed on lowstrength substrates that are reinforced with the use of geosynthetics.

\section{References}

[1] BATOG A., HAWRYSZ M., Stateczność nasypów drogowych formowanych z mieszanek piaskowo-popiołowych $w$ rejonie Wroctawia. Biuletyn PIG 2011, nr 446/2, 445-452.

[2] BATOG A., HAWRYSZ M., Wykorzystanie do budowy nasypów drogowych kruszyw z recyklingu odpadów budowlanych. Geoinżynieria, drogi, mosty, tunele 3/2011.

[3] BATOG A., STILGER-SZYD $Ł O$ E., New approach to assessment of road embankment stability. Studia Geotechnica et Mechanica, Vol. XXXI, No. 3, 2009, 27-46.

[4] BATOG A., STILGER-SZYDŁO E., Stateczność skarp nasypów modernizowanej drogi ekspresowej S-8 w ujęciu Eurokodu 7 i aktualnych przepisów krajowych. Drogownictwo 2010, nr 2, 39-44.
[5] BATOG A., STILGER-SZYD ŁO E., Analiza zapasów stateczności nasypów komunikacyjnych. Przegląd Komunikacyjny, 2014, nr 5, 31-34.

[6] BISHOP A. W., The use of the slip circle in the stability analysis of slopes. Geotechnique, 1955, no 5, 7-17.

[7] KŁOSIŃSKI B., O wymaganiach dotyczących stateczności skarp i zboczy. Zeszyty Naukowo-Techniczne SITK Oddział Kraków, Problematyka osuwisk w budownictwie komunikacyjnym, seria Materiały Konferencyjne, Nr 88, Zeszyt 144, Kraków 2009.

[8] SIMPSON B., Driscoll R., Eurocode 7 a commentary. CRC Ltd., London 1998.

[9] SZYDŁO A., KRAWCZYK B., MACKIEWICZ P., DOBRUCKI D., Recykling nawierzchni betonowych. Raport Serii SPR w ramach grantu "Wykorzystanie materiałów pochodzących z recyklingu", WBLiW PWr., Wrocław 2017.

[10] STILGER-SZYDŁO E., Posadowienia budowli infrastruktury transportu lądowego. Teoria - Projektowanie - Realizacja. Dolnośląskie Wydawnictwo Edukacyjne, Wrocław 2005.

[11] WItUN Z., Zarys geotechniki. Wydawnictwo Komunikacji i Łączności, Warszawa 2000.

[12] EN 1997-1:2004 Eurocode 7. Geotechnical design. Part 1. General rules

[13] EN 1997-2 :2007 Eurocode 7. Geotechnical design. Part 2. Ground investigation and testing

[14] PN-EN 1997-1:2008/NA:2011. Eurocode 7. Geotechnical design. Part 1. General rules. Polish National Annex to Eurocode 7

[15] PN-B-06050:1999 Geotechnika. Roboty ziemne. Wymagania ogólne.

[16] PN-88/B-04481 Grunty budowlane. Badania próbek gruntu.

[17] PN-S-02205:1998 Drogi samochodowe. Roboty ziemne.

[18] BN-64/88931-01 Drogi samochodowe. Oznaczanie wskaźnika piaskowego.

[19] PKN-CEN ISO/TS 17892-4:2009 Badania geotechniczne Badania laboratoryjne gruntów - Część 4: Oznaczanie składu granulometrycznego.

[20] Poradnik ITB nr 424. Ocena stateczności skarp i zboczy. Warszawa 2011.

[21] Rozporządzenie Ministra Transportu i Gospodarki Morskiej w sprawie warunków technicznych, jakim powinny odpowiadać drogi publiczne i ich usytuowanie. Dz. U. Nr 43/1999. 